\title{
Grande imprensa e ideologia da solução autoritária: uma visão Argentina do golpe de 1964 no Brasil pelos olhos do Clarín
}

\section{Great press and ideology of the authoritative solution: an Argentine vision of 1964 coup in Brazil by the eyes of Clarín}

\author{
Helder Gordim da Siveira ${ }^{1}$
}

\begin{abstract}
Resumo
Este artigo analisa a forma pela qual o diário argentino Clarín relatou/representou o golpe civil-militar de 1964 no Brasil enquanto notícia/acontecimento, e busca enfatizar como o discurso jornalístico, a partir da mobilização de imagens e interpretações recorrentes, possivelmente atuou como um importante componente de uma ideologia da solução autoritária frente à crise política e institucional que crescia na região desde, pelo menos, a década de 1950.
\end{abstract}

Palavras-chave: Ditadura Civil-Militar; Argentina-Brasil; jornal Clarín.

\begin{abstract}
This paper analyses the way by which argentine daily Clarín reported/represented 1964 civilian-military coup in Brazil as a new/fact, intending to underline how that journalistic discourse, as mobilize recurrent images and interpretations, possibly acted as an important component of an ideology of authoritative solution face of the political and institutional crises that were growing in the region since as early as the decade of 1950.
\end{abstract}

Keywords: Civilian-Military Dictatorship; Argentine-Brazil; Clarín newspaper.

Artigo recebido em: 30/01/2015

Artigo aprovado para publicação em: 25/04/2015

\footnotetext{
${ }^{1}$ Helder Gordim da Siveira: professor do Departamento de História e do Programa de Pós-Graduação em História da Pontifícia Universidade Católica do Rio Grande do Sul. E-mail: helders@ pucrs.br
}

\section{GANPHLAC}

Revista Eletrônica da ANPHLAC, ISSN 1679-1061, №. 18, p. 189-222, jan./jul. 2015.

http://revista.anphlac.org.br/ 


\section{1- Introdução}

O presente artigo tem como pressuposto básico a consideração segundo a qual os mass media, particularmente a imprensa informativa empresarial, a chamada Grande Imprensa, constituem-se atores complexos que desempenham papel de relevância central na esfera política interna dos Estados e nas relações internacionais contemporâneas. Tem-se fundamentalmente em conta que, por meio dos mecanismos, instituições e estruturas técnicas e mercadológicas de difusão da comunicação de massa, circulam mundialmente, e no interior dos espaços regionais e nacionais, as formas discursivas e imagéticas que se tornarão hegemônicas - considerando-se o espaço de conflito sociopolítico em que se pode constituir o meio de comunicação específico e/ou a variedade deste - na representação e na composição mesma da realidade supostamente objetiva do mundo assim formado, fundada na categoria notícia-acontecimento, basilar do discurso jornalístico.

A designação imprensa informativa empresarial é aqui uma referência genérica aos jornais diários com forma, conteúdo e natureza organizacional resultantes da transição que se verifica, grosso modo, a partir das décadas finais do século XIX, com origem marcada nos Estados Unidos, mas com reflexos imediatos na Europa e na América Latina. Tratava-se da passagem de uma imprensa essencialmente ligada às disputas ideológicas e partidárias da arena pública e estatal para uma atividade jornalística que vinha a reivindicar independência e autonomia em relação àquelas disputas, fundada na perspectiva de profissionalização, de empreendimento empresarial e de objetividade informativa (THOMPSON, 1995; GOLDSTEIN, 1987).

Tal processo de transição não representou, todavia, o abandono da noção liberal clássica da imprensa como tribuna de discussão civilizada das diferentes posições políticas, então de alguma forma análoga ao Parlamento, sem compor o poder estatal. Bem ao contrário, a construção da autonomia do campo jornalístico moderno e o fortalecimento acelerado de seus capitais econômico e simbólico parecem ter concorrido para o reforço da reivindicação doutrinária em torno da assim denominada "liberdade de imprensa", identificada progressivamente com a noção clássica de liberdade de expressão

\section{GANPHLAC}

Revista Eletrônica da ANPHLAC, ISSN 1679-1061, №. 18, p. 189-222, jan./jul. 2015. http://revista.anphlac.org.br/ 
e de informação associada ao Estado de Direito moderno e ao espaço público que, desta forma, este parecia garantir, no âmbito da sociedade civil.

Tem-se aqui, portanto, em conta que as formas de referência deste discurso sobre a esfera política e seus conflitos, nacionais e internacionais - no caso presente, o golpe de 1964 no Brasil noticiado na Argentina - são geralmente embasadas, implícita ou explicitamente, nos conceitos essenciais da matriz doutrinária liberal, que surge ali naturalizada, constituindo uma forma de liberalismo profissional típico do campo.

Entra aqui igualmente em consideração o tema dos fluxos de informação no sistema internacional, particularmente a partir da atuação e da esfera de poder específica das Agências de Notícias (ALLEYNE, 1995; FREDERICK, 1993; THUSSU, 2000), e a recepção/adaptação dos materiais por elas comercializados pelos meios de comunicação no interior dos variados espaços públicos nacionais, tendo-se em vista particularmente as seções ou espaços de notícias internacionais (associadas a análises, interpretações e opiniões especializadas ou de natureza editorial) dos jornais da imprensa informativa empresarial. Este tipo de jornal torna-se, então, ator essencial nas políticas interna e externa de um país, ao se revestir da forma pela qual uma dada visão do espaço internacional - em seus atores, conflitos e padrões de estruturação - se apresente como hegemônica, associada a variadas posições de poder ou a confrontos em torno deste no espaço público nacional, frente aos quais aquela forma de imprensa busca posicionar-se, segundo suas especificidades institucionais e campo diferenciado de interação social (PIZARRO, 2008).

É nesse sentido que aqui se busca pensar o órgão jornalístico, especificamente o argentino Clarín, como ator político complexo ao noticiar para seu público a crise brasileira de 1964 e a solução autoritária/golpista para tal crise.

Para tanto, tem-se como perspectiva teórica, por um lado, os termos da discussão posta por Pierre Nora (1979) em texto célebre a respeito da natureza do acontecimento como categoria constituinte da história contemporânea, e, por outro, a tradição analítica relativa ao conceito de ideologia, atualizado em John Thompson (1995, p. 43-89) como forma geral de interpretação de um possível papel histórico das formas simbólicas no universo do político. Nesse sentido, o autor refere que "a análise da ideologia [...] está primeiramente interessada com as maneiras como as formas

\section{GANPHLAC}

Revista Eletrônica da ANPHLAC, ISSN 1679-1061, №. 18, p. 189-222, jan./jul. 2015.

http://revista.anphlac.org.br/ 
simbólicas se entrecruzam com relações de poder" e que "estudar a ideologia é estudar as maneiras como o sentido serve para estabelecer e sustentar relações de dominação", sendo que "fenômenos ideológicos são fenômenos simbólicos significativos desde que eles sirvam, em circunstâncias sócio-históricas específicas, para estabelecer e sustentar relações de dominação" (THOMPSON, 1995, p. 75-76). Sempre nessa direção, importa, com o autor, destacar que

[...] caracterizar fenômenos simbólicos como ideológicos não coloca, necessariamente, sobre o analista, o encargo de demonstrar que os fenômenos assim caracterizados são, em certo sentido, 'falsos'. O que nos interessa [...] não é [...] a verdade ou a falsidade das formas simbólicas: antes interessam-nos as maneiras como essas formas servem, em circunstâncias particulares, para estabelecer e sustentar relações de dominação (THOMPSON, 1995, p.76-77).

Nesse sentido, considerando a questão do acontecimento acima posta e a possibilidade de interpretar a construção deste no discurso jornalístico moderno como ideologia, é aqui seguida a posição de Muniz Sodré (2009, p. 15) quanto à centralidade da categoria notícia neste discurso:

[...] o jornalismo [...] mobiliza diferentes tipos de discurso, mas a sua moderna centralidade conceitual apoia-se na notícia. E esta forma de captação e comunicação do fato é uma dessas estratégias cuja mitologia liberal-mercadológica costuma fazer esquecer os procedimentos retóricos e imaginosos que presidem à construção do acontecimento.

Igualmente a respeito dessa relação essencial acontecimento-notícia que embasa o discurso jornalístico aqui tratado, por seu turno Miquel Alsina argumenta:

[...] hay que puntualizar que un acontecimiento no es una realidad objetiva, exterior y ajena al sujeto perceptor del mismo [...]. La teoría de la construcción social de la realidad [...] hace referencia a la vida cotidiana. [...] los acontecimientos son 'realidades' históricas determinadas socioculturalmente, como puede apreciarse en la variación histórica que en los mismos se han producido. En la actualidad los mass media establecen unos parámetros para delimitar los hechos que cabe considerar como acontecimientos (1996, p. 1617).

\section{GANPHLAC}

Revista Eletrônica da ANPHLAC, ISSN 1679-1061, №. 18, p. 189-222, jan./jul. 2015. http://revista.anphlac.org.br/ 
Assim, na esteira dos fundamentos conceituais propostos pelos referidos autores, entende-se aqui o discurso jornalístico moderno essencialmente como narrativa embasada na categoria notícia, a qual, mobilizando formas discursivas diversas, constitui o que no plano do espaço público pode se situar como acontecimento, dentro de certos padrões de racionalização que podem tornar-se hegemônicos.

Nesse sentido, sustenta-se que tais formas de construção de um acontecimento, particularmente em um país estrangeiro, operadas pelos meios de comunicação de massa e "afinado com a estrutura ideológica do sistema informativo, cuja forma mais evidente é a presumida transparência da realidade" (SODRÉ, 2009, p.16. Grifo no original), podem representar para certa comunidade de leitores racionalizações de uma ameaça a ser evitada, um exemplo a ser seguido ou uma manifestação de tendência posta como inevitável, apenas para exemplificar.

Nessa direção, Brasil e Argentina representam-se mutuamente como os países mais poderosos no cenário sul-americano e, eventualmente, como polos de uma disputa pela supremacia estratégica em tal espaço, ao menos até os anos 1970. Nessa perspectiva, constroem-se nos círculos diplomáticos e intelectuais, na imprensa informativa empresarial aqui destacada e em outras esferas de produção discursiva representações constituintes de identificação e contraste em ambos os países, em relação a acontecimentos e/ou cursos de longo prazo de suas respectivas ordens socioeconômicas e políticas internas.

Especificamente na conjuntura da década de 1960, contexto aqui considerado, Brasil e Argentina atravessam os impasses condicionados pela crise dos respectivos modelos de modernização socioeconômica das eras varguista e peronista, diante do cenário da Guerra Fria, no qual a Revolução Cubana atuava como um extraordinário catalisador de tensões (CAVLAK, 2007; RAPOPORT e LAUFER, 2000).

Nesse contexto, os elementos discursivos constituintes de uma ideologia da solução autoritária/golpista para tal crise são construídos em parte da grande imprensa sempre desde sua perspectiva específica de interesse, formas de atuação e posicionamento de campo - já ao longo da década anterior. Tal construção associava-se, por diversos mecanismos, às posições de poder dos grupos antivarguista e antiperonista,

\section{CANPHLAC}

Revista Eletrônica da ANPHLAC, ISSN 1679-1061, №. 18, p. 189-222, jan./jul. 2015. http://revista.anphlac.org.br/ 
no interior das Forças Armadas e em diversas esferas civis, sem ser delas meramente derivada, de forma geral. Os condicionantes políticos do suicídio de Vargas e da deposição de Perón pela Revolução Libertadora de 1955 são emblemáticos das ações institucionais e extra-institucionais desses grupos (DONGHI, 2000; DE RIZ, 2000; POTASH, 1994; GOLDWERT, 1972; ROMERO, 2004).

É nessa perspectiva que propomos interpretar o discurso veiculado no diário Clarín, ao compor a rede de notícias-acontecimentos em torno da crise do governo Goulart e do golpe de Estado que implanta a ditadura civil-militar no Brasil, como um contributo político essencial para a veiculação, ou reprodução, sempre nos termos da inserção sociopolítica da imprensa informativa empresarial, de uma ideologia da solução autoritária. Vale dizer, como uma forma de construção dos acontecimentos a qual mobiliza o sentido - notadamente pela incorporação dos fundamentos da visão anticomunista/antipopulista pelo liberalismo de profissão - para estabelecer uma lógica narrativa em cujo conteúdo explica-se, racionaliza-se e se legitima a ruptura institucional no país vizinho, posto tradicionalmente como espelho, mesmo que para visualização de contrastes relativamente à Argentina.

O corpus documental trabalhado se compôs de todas as edições do Clarín do mês de março até 5 de abril de 1964. Destacaram-se, inicialmente, as matérias relativas aos acontecimentos que marcaram a crise final do governo Goulart e, a seguir, analisaram-se todas as edições que cobrem o desfecho golpista, a partir de $1^{\circ}$ de abril. Nos termos teóricos acima postos, a análise é estritamente qualitativa, como interpretação das formas possíveis de operação ideológica na construção da notícia, seja via material das agências internacionais, seja nas matérias de conteúdo analítico ou opinativo de editoriais, colunistas e enviado especial, considerando-se um conteúdo possível dos textos e as formas jornalísticas de destaque e posicionamento destes nas edições específicas do diário. A interpretação assim proposta refere-se exclusivamente à esfera de produção do discurso, apoiando-se em uma possibilidade de leitura possível no conjunto do público leitor do diário - provavelmente, uma parcela letrada com instrumentos intelectuais idôneos para fundamentar interesse no noticiário internacional e compartilhar conceitos-chave da produção textual -, não se ignorando a existência,

\section{GANPHLAC}

Revista Eletrônica da ANPHLAC, ISSN 1679-1061, №. 18, p. 189-222, jan./jul. 2015. http://revista.anphlac.org.br/ 
aqui não trabalhada, das múltiplas e diferenciadas esferas de recepção do discurso jornalístico como forma de comunicação de massa.

\section{2-O Clarín: Nascimento e Trajetória no Jornalismo Argentino}

Em 28 de agosto de 1945, com a primeira página de logotipo vermelho dominada pelas notícias referentes ao término da Guerra, tiragem de 150.000 exemplares de 20 páginas, ao preço de 5 centavos - cerca da metade daquele dos grandes diários -, aparecia nas ruas de Buenos Aires o matutino Clarín, em formato tabloide, inspirado no inglês The Mirror e à semelhança do argentino El Mundo. Tratava-se de um empreendimento do político, jornalista e estancieiro Roberto Jorge Noble, dissidente do socialismo argentino da década de 1920. Noble, nos anos 1930, alinhando-se aos grupos anticomunistas, fundara o chamado socialismo independente e chegara a ocupar a pasta de ministro do interior do governo conservador da província de Buenos Aires, presidido por Manuel Fresco.

Ao que parece, o Clarín representava para seu proprietário um projeto de natureza tanto política quanto comercial, confluência de campos característica, aliás, do jornalismo moderno. Para tentar superar a relativa obscuridade, por um lado, e lucrar com o empreendimento, por outro, Noble vendera uma de suas principais propriedades rurais para efetivar a compra de bobinas de papel, artigo bastante caro nas condições do pós-guerra. No mais, com um investimento inicial da ordem de 1.250 .000 dólares à época, o Clarín surgia em sede muito modesta, na rua Moreno, com pessoal reduzido, embora qualificado e experiente, quando alugava as impressoras de Notícias Gráficas e com um futuro bastante incerto.

Sobre o surgimento do novo jornal portenho, Carlos Ulanovsky afirma que “Clarín salió a la calle con la idea de apoyar los cambios de un país tradicionalmente agrícola-ganadero que ahora aspiraba a hacerse fuerte en grandes, medianas y pequenas industrias y a desarrollarse más dentro de fábricas que en el campo" (2005, p. 109).

Até o final da década de 1940, as incertezas inicias converteram-se em um grande êxito empresarial, pois o Clarín crescia vertiginosamente em vendas, em influência e popularidade. Carlos Ulanovsky alinha alguns fatores deste sucesso do

\section{CANPHLAC}

Revista Eletrônica da ANPHLAC, ISSN 1679-1061, №. 18, p. 189-222, jan./jul. 2015. http://revista.anphlac.org.br/ 
matutino portenho. Primeiramente, o autor aponta nesse sentido a eficiência do sistema de distribuição, pelo qual o Clarín chegava aos pontos de venda na capital federal argentina antes dos demais matutinos; e, nos primeiros anos, ele renunciou a disputar posições no interior do país. O diário de Noble, nesse período de crescimento inicial, apelava basicamente para os temas locais de Buenos Aires, conferia destaque, até então inédito na grande imprensa informativa, às seções de esportes e espetáculos, tidas como banais ou "populacheras" pelos demais grandes jornais. Durante o primeiro governo de Perón, segue o autor, Clarín constrói uma imagem pública de independência, não sofrendo controle excessivo por parte do regime que se implantava, o qual parecia não lhe reconhecer poder de influência em que pesasse o crescimento permanente de sua circulação e vendas (2005, p. 111-112).

De resto, o Clarín iria atravessar a era peronista, até 1955, usufruindo dessa posição independente, em contraste inicial com os matutinos La Prensa, La Nación e El Mundo e os vespertinos La Razón, Crítica e Noticias Gráficas, que mantiveram, a princípio, posição abertamente hostil ao líder popular e sua política, a qual vinha desde os tempos de Perón como ministro do trabalho e previdência do governo Farrel.

Quando chegou à presidência, em 1946, Perón de fato contava apenas com o apoio declarado do diário La Época. Em contraste, quando de sua queda em 1955, o líder justicialista controlava uma grande cadeia nacional de jornais, composta por $L a$ Razón, Democracia, El Laborista, La Época e Notícias Gráficas, além de cinco diários do interior e outros órgãos que não se articulavam oficialmente com a cadeia peronista, mas mantinham posições mais ou menos sistemáticas de apoio à linha política do regime (SIRVÉN, 2011; DA ORDEN e PIRRO, 2007).

Fora deste grande círculo da imprensa oficialista ou semioficialista, entre os grandes diários permaneceram La Nación, La Prensa e Clarín, mais fiéis aos princípios do que chamamos acima de Liberalismo profissional, definidor da base da percepção política do jornalismo empresarial. Clarín, todavia, em contraste com os dois primeiros, evitava apresentar-se como de oposição aberta e sistemática, preferindo alimentar a imagem de independência, talvez mais afeita àquela forma de posicionamento. Segundo Carlos Ulanovsky, as restrições de toda ordem e a censura peronista recaíam, assim, mais pesadamente sobre La Nación e La Prensa, enquanto que o Clarín podia absorver

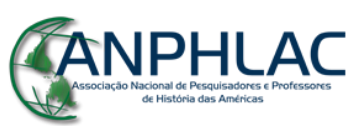

Revista Eletrônica da ANPHLAC, ISSN 1679-1061, №. 18, p. 189-222, jan./jul. 2015. http://revista.anphlac.org.br/ 
leitores, anunciantes e a importante renda dos classificados do público leitor desses grandes jornais, opositores sistemáticos do peronismo.

No pós-1955, sob a égide da tutela militar sobre o sistema político argentino oriunda da Revolución Libertadora, o Clarín manteria posição estritamente legalista sob os governos Frondizi e Illia, representantes, respectivamente, das duas facções em que se cindira o radicalismo.

Ao final da década de 1950, o campo jornalístico argentino via os efeitos de um intenso processo de modernização e renovação, em parte determinado pela abertura do país aos mercados e centros de informação internacionais, notadamente a partir de Frondizi (LLAIRÓ e SIEPE, 2003). Verifica-se um boom editorial na Argentina, com destaque para o surgimento de novas revistas semanais ao estilo das estrangeiras Time, Newsweek, Der Spiegel e L'Express, que igualmente circulavam pelas regiões mais urbanizadas, notadamente Buenos Aires. Era o caso, no princípio dos anos 1960, de Primera Plana, Panorama, Confirmado, Todo e Gente, para exemplificar, que disputavam um público leitor de estratos sociais médio e alto que fixava novos hábitos de consumo e de comportamento, assim como competiam pela renda da nova publicidade ligada às agências e empresas multinacionais que se instalavam no país. Uma nova geração de jornalistas, oriundos da academia e do campo literário, ingressam nos diários e revistas semanais. O Clarín não ficaria alheio aos novos tempos:

Los cambios llegan a Clarín. Conducida por Moisés Scherbor Jacoby y Luis Clur, la redación reunía a muchos consagrados de Crítica [...] y a jóvenes como Esteban Peicovich, Roberto Cossa, Rodolfo Rabanal y Valentin Vergara. Por decisión de Jacoby, el logo de Clarín, hasta entonces em rojo, pasa a imprimarse em negro, pero son otras las cuestiones que dan color al diário: la sección económica que maneja Oscar Garcia Rey y la información militar que abastece, entre otros, Enrique Ramos de Madariaga (ULANOVSKY, 2005, p. 170)

A renovada redação do Clarín de fato abrigava, na virada da década de 1950, nomes que em seguida teriam enorme relevância no jornalismo argentino: Hector Ricardo Garcia, que fundaria o diário Crônica, Jacobo Timerman, que criaria o diário La Opinión e as revistas Primera Plana e Confirmado, Julio Ramos, de Ámbito Financiero e Bernardo Neustadt, que dirigiria Todo.

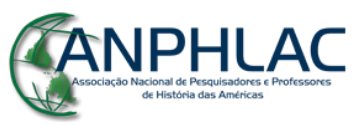

Revista Eletrônica da ANPHLAC, ISSN 1679-1061, №. 18, p. 189-222, jan./jul. 2015. http://revista.anphlac.org.br/ 
Desse modo, o diário de Noble, que viria a falecer em 1969, afirmava-se como grande empresa jornalística em um cenário de intenso crescimento e diversificação do campo. Apesar de sofrer relativa perda na competição por publicidade, juntamente com La Nación e La Prensa no começo dos anos 60, em 1963 o Clarín torna-se o jornal de maior circulação na capital argentina (LONGHI e SILVEIRA, 2010, p. 158), posição que se consolidaria nos anos seguintes.

A cobertura da crise final do governo Goulart e do golpe de abril de 1964 nas páginas do Clarín insere-se em um contexto particularmente dramático das relações entre os campos político e jornalístico na Argentina. Muitos autores chegam mesmo a sustentar a existência de um "golperiodismo" contra o governo de Arturo Illia, da Unión Cívica Radical del Pueblo (TARONCHER, 2009; POTASH, 1972, SANCHEZ, 1983; ULANOVSKY, 2005; DÍAZ, 2007; PANDOLFI e GIBAJA, 2008), fundado em prática abertamente conspiratória e/ou na difusão de uma forma de discurso anticomunistaantipopulista posto como modernizador, o que teria um desfecho com o golpe de 1966. Os exemplos mais destacados nessas perspectivas de análise são as revistas semanais Primera Plana e Confirmado, mas igualmente se destacam a virulência dos editoriais e a oposição sistemática ao governo Illia promovida pelos grandes diários, como La Nación e La Prensa, bem como o papel de colunistas desses diversos órgãos, como Juan José Guiraldes, Mariano Montemayor e Mariano Grondona.

\section{3- O Clarín e os Sentidos da Crise e do Golpe no Brasil}

Ao longo da segunda quinzena de março e princípio de abril de 1964, o diário de Noble elabora para seu público leitor a cadeia de notícias-acontecimentos que compõem o quadro da crise institucional no país vizinho, por meio de matérias informativas baseadas nas agências internacionais - principalmente a Associated Press (AP), a France Press (AFP) e a ANSA -, artigos assinados e editoriais. O Brasil foi tema em praticamente todas as edições do periódico, embora, diferentemente de La Nación, por exemplo, o país só ganhe a primeira página a partir de 31 de março.

Pode-se verificar certo contraste entre as matérias predominantemente informativas e aquelas com teor mais diretamente posicionado ou opinativo no jornal.

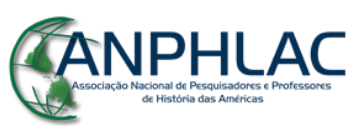

Revista Eletrônica da ANPHLAC, ISSN 1679-1061, №. 18, p. 189-222, jan./jul. 2015. http://revista.anphlac.org.br/ 
Aquelas, construídas basicamente a partir do material das agências, acabam por se conformar de modo bastante semelhante a outros grandes diários, como La Nación, podendo-se ali verificar estratégias variadas de construção de imagens entrecruzadas de um país à beira do caos e sob grave ameaça de ruptura da ordem institucional por iniciativa do governo Goulart, associado a variadas organizações comunistas. Nas referidas matérias de caráter opinativo, entretanto, o jornal tende a exibir sua face fundamentalmente legalista, a partir da qual se relacionava com o governo Illia e que marca de forma particular o que temos chamado de liberalismo profissional, base doutrinária característica da imprensa informativa empresarial.

A notícia relativa ao comício de 13 de março, baseada em material da AP, traz como manchete "Goulart Promulgó la Reforma Agraria y la Nacionalización de Todo el Petróleo (14/03/1964, p. 4). No texto em destaque sob a manchete, que se põe como introdução ao restante da matéria, lê-se:

[...] mientras tres mil soldados con cascos de acero y armados con ametralladoras livianas montaban guardia en la plaza central de Rio de Janeiro, el presidente João Goulart firmó el discutido decreto de reforma agraria, que abre el camino a la distribuición de tierras entre centenares de miles de campesinos brasileños que no las poseen ((14/03/1964, p. 4)).

O texto dá o tom da matéria, pela qual se pode observar um presidente a se apoiar nas forças armadas para impor decretos com propósitos "populistas" que claramente ameaçavam de variadas formas o instituto basilar da propriedade privada.

A matéria destaca como personagens principais do acontecimento, além do próprio presidente, o governador Carlos Lacerda, seu adversário "irreconciliable”, que o texto informa haver proibido o comício, e seu cunhado, deputado Leonel Brizola, de cujo discurso se destaca a exortação significativa para o quadro: "los que quieren un gobierno nacionalista y popular que levanten la mano".

O texto se conclui com destaque da fala do presidente, na qual este aparece enfrentando uma oposição potente e difusa e, apesar ou sobre esta, anunciando urgência excepcional para as reformas de toda ordem, posta em prazos determinados, como o de 60 dias para começar a distribuir terras.

\section{GANPHLAC}

Revista Eletrônica da ANPHLAC, ISSN 1679-1061, №. 18, p. 189-222, jan./jul. 2015. http://revista.anphlac.org.br/ 
As repercussões do comício são construídas ainda em matéria dominada pelos textos da AP, cujo teor a diagramação do Clarín tende a reforçar. A Manchete, nesse sentido, é "Brasil: Severas Críticas a Goulart" (15/03/1964, p. 7). De fato, a suposta repercussão do comício é toda posta em termos condenatórios e negativos, seja na palavra da oposição ao governo, à qual a agência dá voz exclusiva nos textos informativos, seja na difusão do posicionamento de vários jornais do Rio de Janeiro, que surgem como representantes de um personagem coletivo recorrente: a "imprensa brasileira independente", desde sua posição de órgão-chave de uma ordem liberalocidental.

Desse modo, o texto destacado em corpo maior abaixo da manchete, desde sua posição introdutória, dá voz a Carlos Lacerda. Surge ali o governador da Guanabara por meio de seu jornal Tribuna da Imprensa afirmando: “'Cayeron las caretas. Empezó la guerra revolucionaria. El jefe público del partido de la subversión es Goulart, hasta que los comunistas estimen oportuno reemplazarlo"” (Idem). Na voz de Lacerda, a imagem recorrente de Goulart, o presidente, a um tempo ingênuo e subversivo, posto na condição de líder inconsciente de uma ruptura institucional iminente de conteúdo comunista.

Quanto ao restante da imprensa brasileira, o texto originário da AP difundido no Clarín excetua a Última Hora, colocada como "órgano del partido laborista" e a quem não se dá nenhuma visibilidade, ao contrário da Tribuna de Lacerda, para informar ao leitor argentino que "todos los grandes diarios de Rio juzgan hoy severamente el mítin popular celebrado ayer con la participación del presidente Goulart" (Clarín).

A matéria - ladeada por radiofoto do comício exclusiva da AP que ostenta legenda na qual o Clarín novamente destaca a presença de contingente militar de segurança - estrutura-se assim com os posicionamentos do Jornal do Brasil, de $O$ Jornal e do Jornal do Comércio, de Assis Chateaubriand. Em todos são destacadas passagens que colocam o presidente e seus "aliados comunistas" como golpistas, com a dita democracia brasileira, assim, em cheque. Ameaça de violação da ordem constitucional e exortação pública à luta de classes são elementos que se justapõem para compor a imagem do governo e da crise brasileira.

\section{GANPHLAC}

Revista Eletrônica da ANPHLAC, ISSN 1679-1061, №. 18, p. 189-222, jan./jul. 2015. http://revista.anphlac.org.br/ 
Significativamente, a matéria se encerra dando voz a Joseph Macedo, suposto líder de fazendeiros de Minas Gerais, que surge na cena do acontecimento a afirmar: "'los agricultores están unidos y armados para defender sus propiedades, cueste lo que costare","

Nos dias subsequentes, o Clarín continua a veicular informações das principais agências que tendem a constituir um quadro de intensa crise política, talvez já marcada por características de um confronto civil que ensaiava assumir proporções nacionais, com violência revolucionária. Nesse tom, direta ou indiretamente, são noticiados a ação policial contra os grupos de estudantes que tentavam impedir João Pinheiro, líder da reforma agrária brasileira, a falar na Faculdade de Direito, no Rio de Janeiro (18/03/1964, p. 5); a ação de bloqueio de estradas por grupos de desempregados em Brasília, que o Clarín confunde com o Rio de Janeiro (19/03/1964, p. 9), e a greve dos trabalhadores de telecomunicações, em protesto contra a demissão de funcionários da All America Radio (Clarín).

É nesse quadro informativo, composto pelo material das agências, que nas páginas do Clarín seria construída a notícia-acontecimento da Marcha da Família com Deus pela Liberdade, em São Paulo. A Manchete, em grande medida, anuncia e reforça o teor do texto proveniente da AP e da ANSA: "San Pablo: Gigantesca Demostración Contra el Programa de Joao Goulart” (20/03/1964, p. 2). O anúncio se explicita com a voz do governador paulista Adhemar de Barros, que é posta logo abaixo da manchete, em corpo destacado: "advierte Adhemar de Barros que Brasil puede resultar otra Cuba".

A matéria se abre com realce do caráter absolutamente pacífico da marcha, posto na voz da polícia paulista. A paz apenas teria sido interrompida brevemente por culpa de um homem que teria provocado os manifestantes, gritando "Viva Jango [...] y viva el comunismo" (20/03/1964, p. 2). Pelas agências em suas matérias, as vozes que se associam de algum modo à marcha, posta como "evidente réplica a la concentración que hubo en viernes en Rio de Janeiro", são as de Adhemar de Barros e de Eurico Gaspar Dutra, este, por meio de uma destacada entrevista concedida ao Jornal do Brasil, sempre colocado como "diario independiente".

As manifestações de Adhemar e Dutra ocupam a maior parte do espaço destinado à notícia da Marcha e parecem conferir o pano de fundo do sentido da

\section{CANPHLAC}

Revista Eletrônica da ANPHLAC, ISSN 1679-1061, №. 18, p. 189-222, jan./jul. 2015. http://revista.anphlac.org.br/ 
manifestação anti-Goulart no interior do quadro da crise brasileira. Por seu turno, o governador de São Paulo aparece mais uma vez, com a afirmação: "Brasil se encuentra en una situación difícil, tal vez la más difícil de toda su historia". E seguia: "el país se halla frente a dos caminos: seguir el cauce de la democracia, en la lucha por su evolución dentro de los princípios de las libertades humanas, o bien ceder a la presión de los actuales dirigentes de la nación y tranformarse en una nueva Cuba”.

De seu lado, Dutra - "bajo cuya presidencia el gobierno democrático se consolidó en Brasil" - aparece igualmente advertindo sobre a gravidade da situação no país e menciona mesmo o risco iminente de "una irremediable secesión interna". Significativamente, a notícia-acontecimento da Marcha da Família é encerrada com notas sobre o declínio da bolsa e a elevação dos índices inflacionários.

Os protagonistas da oposição a Goulart e o processo das reformas seguem ganhando visibilidade nas páginas do Clarín a partir das agências de notícias ao longo dos dias seguintes. A Manchete do dia 22 de março é ilustrativa nesse sentido: "Brasil: Señalan los Adversarios de Goulart el Peligro de Una Dictadura". E, em corpo menor, como complemento: “Afírmase que es el Objectivo del Presidente" (22/03/1964, p. 6). O destaque inicial da matéria, em tipo e corpo destacados, é conferido pela voz do governador de Minas Gerais, Magalhães Pinto, posto como de tendência liberalmoderada, que aparece ali afirmando: aún cuando las transformaciones revolucionarias [...] requeridas por el proceso inflacionario no puedan ser ignoradas, nosotros afirmamos que la revolución implantada desde arriba no es outra cosa que un golpe de estado". E concluía: "Nosotros estamos dispuestos a combatir el golpe".

Significativamente, a matéria na qual se reforça a imagem de um presidente golpista é concluída com dados "objetivos” fornecidos por outra agência de notícias (AFP) que dá conta da elevação, em ritmo excepcionalmente acelerado, do custo de vida exposto em números provenientes da Fundação Getúlio Vargas.

Na mesma edição de 22 de março, na Seção assinada de análise política Panorama Americano, (p. 26) surge no Clarín um primeiro posicionamento explícito sobre o recente recrudescimento da crise brasileira. É notável como essa matéria de conteúdo analítico-opinativo, em seção que sempre expressa posição muito próxima

\section{CANPHLAC}

Revista Eletrônica da ANPHLAC, ISSN 1679-1061, №. 18, p. 189-222, jan./jul. 2015. http://revista.anphlac.org.br/ 
àquelas de caráter propriamente editorial, contrasta com as matérias "informativas", baseadas nas agências, conforme mencionamos acima.

É ilustrativa nesse sentido a forma como o articulista abre a seção:

El paso de Goulart hacia un plán de reformas que, necesariamente, debía irritar a las derechas (alérgicas sobretodo a cualquier novedad de tipo social baseada en 'expropiaciones') trajo las consecuencias previstas. Durante toda la semana, y a partir de la gigantesca manifestación 'trabalhista' realizada en Rio de Janeiro, se movilizaron los ya habituales recursos para contrarrestar todo giro (o siquiera un simple amago) hacia la izquierda (Panorama Americano, 22/03/1964, p. 26).

O texto sustenta ser a situação previsível a partir dos compromissos à esquerda assumidos por Goulart, pelo menos desde o plebiscito de 1962, que lhe devolvera as prerrogativas presidenciais, o que teria sido desde ali adiantado pelo analista nas páginas da seção Panorama Americano. Segundo a análise, o presidente teria, inclusive, trabalhado desde ali para compor um decisivo respaldo militar para apenas então colocar em prática seu plano recente de reformas. O autor não acredita, absolutamente, na possibilidade de um golpe de Estado, apesar dos projetos nessa direção; sustenta sempre que a solução haveria de se dar no campo políticoinstitucional, no qual a figura de Juscelino Kubistchek e seu partido "de centro" provavelmente seriam os vitoriosos, a partir de 1965.

É assim que, contrastando com outros órgãos da imprensa argentina no contexto e seguindo o legalismo em que se baseava o jornal, a partir do que chamamos liberalismo profissional para se posicionar explicitamente no contexto político interno da Argentina, pode o Clarín veicular uma análise bastante singular na grande imprensa, segundo a qual "la situación en Brasil no es tan 'grave' como lo han sostenido algunos líderes (interesados en que lo séa). E, a partir dessa assertiva básica, as previsões: "habrá conflictos, [...] pero no decisivos cuando se lleven adelante las reformas; [o presidente] debe contar con suficiente apoyo militar; se intentarón crear más dificuldades al gobierno, inclusive promoviendo actos de violencia". E assim: "puede preverse un período de inestabilidad, desordenes etc., pero no un cambio de estructuras".

\section{GANPHLAC}

Revista Eletrônica da ANPHLAC, ISSN 1679-1061, №. 18, p. 189-222, jan./jul. 2015. http://revista.anphlac.org.br/ 
O jornal viria a explicitar posicionamento editorial sobre a situação brasileira, mais ou menos em acordo com o exame do articulista da seção Panorama Americano, na edição do dia 26 de março. O título da peça editorial expressa o argumento central do texto: "Brasil, en un Paréntesis" (26/03/1964, p. 6).

Situando o princípio da crise então presente na renúncia de Janio Quadros, em agosto de 1961, a qual qualifica como "un injustificable arresto temperamental", o editorial do Clarín não deixa de reconhecer a gravidade da situação:

Se llega así al panorama de hoy: un ovillo enmaranhado en que los hilos políticos, los económicos y los sociales están en tal forma entrelazados que solo por abstración mental pueden considerarse aisladamente. Y lo mismo puede decirse de cada acto de gobierno (Clarín).

Isso posto, o texto faz um balanço dos principais atos governamentais, com manifestação de apoio e concordância com aqueles que coloca como do campo econômico e social, como a reforma agrária, qualificada como "uma medida acertada". Todavia, aqueles atos ditos do campo político são condenados, na medida em que, segundo o editorial, visariam claramente à continuidade de Goulart na presidência, em desacordo com a ordem constitucional brasileira. Assim, o editorialista pode sustentar uma posição legalista, análoga àquela que o Clarín, em linhas gerais, exibia frente à política doméstica argentina: "si el golpe revolucionário que algunos propugnan es condenable, no lo és menos la perpetuación en el poder". E segue: "una cosa es la continuidad de las instituciones y outra muy distinta la de las personas".

De todo modo, o jornal não deixa de reproduzir, ao menos parcialmente, a ideia de caos, bastante recorrente na grande imprensa em ambos os países:

Todo ese proceso político no podia sino gravitar negativamente en la vida econômica del país. Inestabilidad, distracción y dispersión de fuerzas, incertidumbre, falta de conducción, objectivos no del todo claros por un lado y oposición sistemática por el outro: He ahí una serie de elementos que configuran un cuadro nada alentador.

É precisamente esse quadro nada alentador que o editorial qualifica como um parêntesis na vida brasileira. Parêntesis de frustração que teria sido aberto após o período de Juscelino Kubistchek, no qual teriam sido lançadas as bases para o desenvolvimento brasileiro que, no momento, segundo o editorial, encontrar-se-ia

\section{GANPHLAC}

Revista Eletrônica da ANPHLAC, ISSN 1679-1061, №. 18, p. 189-222, jan./jul. 2015. http://revista.anphlac.org.br/ 
"frenado" e "desvirtuado". É assim que o editorial termina, deixando possibilidades em aberto para o fechamento do parêntesis histórico brasileiro, talvez em analogia com a situação argentina: "aquellas bases aún están en pie. Pero Brasil vive entre parêntesis; un parêntesis que ya se prolonga demasiado. Y la vida de las naciones no admite pausas".

Pode-se notar, portanto, um contraste entre as opiniões expressas do jornal em matéria assinada e editorial e o conteúdo geral das matérias postas como informativas, bem mais numerosas e constantes nas edições examinadas. Naquelas, percebe-se uma visão legalista da situação brasileira, embasada em uma condenação a qualquer forma de ruptura institucional na ordem da democracia representativa, seja por parte do governo, seja por parte das oposições, sem que uma ameaça comunista aparecesse mobilizada para justificar aquelas formas de ação, à direita. Já nas matérias informativas, o jornal veicula sem restrições, e mesmo reforça por meio das estratégias acima discutidas, uma visão recorrente na grande imprensa da situação brasileira, marcada pelo anticomunismo e pela justificação, velada ou explícita, de uma ruptura reativa e depuradora da ordem institucional.

Um exemplo marcante nesse sentido pode ser notado na forma como o jornal noticia, na mesma edição do editorial examinado, vê o projeto do governo brasileiro de estabelecer o monopólio estatal sobre as importações de papel para jornais, com base em material da AP e da Reuter. A manchete dá novamente voz a um personagem constante nas páginas do Clarín, via agências: "Goulart Quiere Emular a Vargas, Dijo Lacerda" (26/03/1964, p. 7). E o texto introdutório, em tipo e corpo de destaque:

El gobernador Lacerda dice que El presidente João Goulart, con ayuda de los comunistas, quiere perpetuarse en el poder. Lacerda [...] dice [...] que no hay la menor duda de que Goulart no quiere elecciones, y trata de imitar al dictador Getulio Vargas.

No interior do texto repete-se a visão de um presidente golpista e ingênuo, na verdade manipulado quando pensa manipular "os comunistas". A notícia do projeto do monopólio do papel é então construída de forma completamente subordinada às supostas intenções golpistas do presidente, em que pese breve menção à versão oficial,

\section{CANPHLAC}

Revista Eletrônica da ANPHLAC, ISSN 1679-1061, №. 18, p. 189-222, jan./jul. 2015. http://revista.anphlac.org.br/ 
que alegava economia de divisas e fim dos privilégios de taxa cambial nas operações de importação em causa. De fato, a matéria se encerra com reprodução da posição do diário O Jornal, posto, uma vez mais, como exemplo de uma suposta posição geral da “imprensa brasileira independente". Assim se ouve a voz do diário carioca no Clarín: "lo que más preocupa al señor Goulart y a su digno cuñado, el diputado Leonel Brizola, es la libertad de prensa. [...] Ambos [...] la consideran intolerable y, en unión de sus consejeros comunistas, estudian frenéticamente la forma de liquidarla”.

As matérias com teor informativo a respeito da rebelião dos marinheiros, na semana santa que precede o golpe de Estado no Brasil, seguem as linhas gerais dessas estratégias.

A primeira notícia a constituir o acontecimento aparece na edição de sábado, 28 de março, dia seguinte à rendição dos amotinados. A sub-manchete é significativa no sentido de enquadrar o fato na moldura de uma quebra dramática de hierarquia: "Un Cabo Drigió la Rebelión que Provocó la Caída de un Ministro" (28/03/1964. p. 5). Com base em textos da AP, da ANSA e da AFP, o tema ocupa praticamente toda a página, significativamente encabeçada à esquerda por um texto ao qual a diagramação confere destaque pelo enquadramento diferenciado, no qual o leitor é informado que "fue total la indiferencia del pueblo brasileño ante la crisis". O texto segue informando que o feriado de semana santa e as ocupações com viagens e outras formas de descanso teriam sido mais do que suficientes para que a grave crise política não tivesse sido sequer percebida pelo ente coletivo e difuso que se põe como o "povo brasileiro". É interessante notar que não apenas o Clarín, mas vários outros órgãos da grande imprensa na Argentina e no Brasil, passa a conferir destaque para o que é colocado como "apatia e indiferença popular" em relação à crise e seu desfecho, a qual é enquadrada progressivamente como um movimento restrito às elites políticas e ao interior do aparelho de Estado brasileiro.

Um dos outros dois textos em destaque de enquadramento e que emolduram, à direita e abaixo, o conteúdo central da matéria diz respeito à presença junto ao cabo Anselmo, líder do movimento, do marinheiro José Cândido, então com 92 anos de idade, que liderara a revolta da chibata de 1910, o que parece conferir dimensão histórica dramática ao episódio. O outro texto apresentado como informação destacada

\section{CANPHLAC}

Revista Eletrônica da ANPHLAC, ISSN 1679-1061, №. 18, p. 189-222, jan./jul. 2015. http://revista.anphlac.org.br/ 
se refere à censura sobre a imprensa, supostamente exercida pelo governo, que teria permitido somente a veiculação de comunicados oficiais sobre a rebelião, ao solicitar uma forma de "colaboração". Reproduzindo novamente o que põe como posição da imprensa brasileira, o Clarín qualifica o fato como "censura con otro nombre".

Parece relevante para a análise aqui proposta o modo como aparentemente a notícia-acontecimento se constitui. Trata-se de gravíssima e histórica quebra de hierarquia funcional nas Forças Armadas, à qual o "povo" assiste com indiferença e sob censura governamental.

Nos dois dias seguintes, que antecedem imediatamente o início do golpe de Estado, os desdobramentos da rebelião dos marinheiros são noticiados ao público leitor argentino como um impasse, progressivamente insuperável por vias institucionais, entre o Alto Comando das Forças Armadas e o governo Goulart, visto sempre com indiferença pelo "povo brasileiro".

Nessa direção, o jornal dará voz, por meio das agências internacionais (um enviado especial produzirá textos apenas a partir de abril), apenas aos jornais brasileiros qualificados como "imprensa independente" e aos adversários civis e militares do governo. É assim a manchete da edição do dia 29 de março: "Enfrentan a João Goulart los oficiales de la Marina" E, em texto de destaque sob a manchete principal: "afirman que resistirán por todos los medios de la comunización” (29/03/1964, p. 3).

Essa caracterização da rebelião e da dita condescendência governamental como uma vitória da "esquerda comunista" e como anúncio de um golpe liderado pelo presidente é, uma vez mais, reforçada pela voz da "imprensa brasileira":

[...] durante el dia circularon insistentes rumores de que Goulart se proponía decretar el estado de sitio, colocando a Brasil bajo la ley marcial. De estas versiones se hizo eco la prensa, que en su mayoría interpretaba el desenlace de la revuelta como una vitoria izquierdista sobre las autoridades navales del país (Clarín, 29/03/1964, p. 3).

No mesmo sentido ocorre a visibilidade ao posicionamento de Helio Fernandes, diretor do nada independente Tribuna da Imprensa, para quem "Goulart obtuvo una vitoria total con la desorganización de la marina, que era la única fuerza hostil [...] a los métodos de gobierno". Na mesma direção, a manifestação de um certo

\section{GANPHLAC}

Revista Eletrônica da ANPHLAC, ISSN 1679-1061, №. 18, p. 189-222, jan./jul. 2015. http://revista.anphlac.org.br/ 
"almirante anónimo" ao "independiente" Jornal do Brasil, segundo a qual "'los acontecimientos de ayer señalan el fin de la marina, que sufre la doble humillación de ver su espíritu de cuerpo quebrantado y sentirse bajo la tutela del ejército"”. Acrescentase ao quadro o depoimento do deputado da União Democrática Nacional (UDN) Lúcio Adauto Cardoso, para quem "entre la disciplina y el motín, el gobierno escoge el motín". Todas essas vozes encabeçadas pela sub-manchete, com reticências: "Una Amplia Sonrisa..." O sorriso é atribuído a Goulart, quando deixava o Palácio das Laranjeiras para se dirigir a Brasília. De resto, as reticências em manchete parecem conter mais "informações" do que supõe o texto.

$\mathrm{O}$ tom geral das matérias informativas segue esse mesmo rumo ainda na edição do dia 30, quando se noticia um ultimato da Marinha, talvez apoiado pelo Exército, para a punição dos marinheiros anistiados. Uma das manchetes caracteriza a situação no Brasil pelos substantivos "Tensión y Desconcierto" (30/03/1964, p. 7). Dáse uma vez mais preferência completa às vozes de oposição ao governo, que aparecem com alusão a um iminente decreto de lei marcial no país. É interessante notar que se dá voz a um coletivo, sem nomes referenciais, posto como "los izquierdistas", que aparecem, talvez em coro, afirmando - entre aspas - terem considerado "satisfactorio y estimulante" o suposto resultado da crise recente.

$\mathrm{Na}$ edição do dia 31 de março - com as primeiras notícias das ações para depor Goulart, um golpe que pode, em face do quadro narrativo em que se põe, ser caracterizado direta ou indiretamente como reativo ou preventivo - o Brasil ganha inteiramente a primeira página do Clarín.

O quadro geral das notícias sobre o país vizinho é composto a partir de três eixos essenciais: a ameaça de greve nacional por parte da Confederação Geral dos Trabalhadores (CGT), o discurso de Goulart no dia anterior, no Automóvel Clube do Rio de Janeiro e, significativamente, a posição do Departamento de Estado norteamericano sobre a situação brasileira.

A fala de Goulart é posta como "el discurso más violento que pronunció desde que asumió el poder" (31/03/1964, p. 1). No desenvolvimento da matéria, mais uma vez por via das agências, destacam-se trechos do pronunciamento presidencial, nos quais Goulart surge denunciando atividades conspiratórias para o depor e anunciando

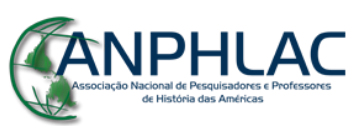

Revista Eletrônica da ANPHLAC, ISSN 1679-1061, №. 18, p. 189-222, jan./jul. 2015. http://revista.anphlac.org.br/ 
que resistirá, aparentemente por todos os meios disponíveis, para garantir seu mandato e a continuidade das reformas ditas de base. A figura e os gestos do presidente surgem no texto de forma significativa para a composição da imagem: "su voz se alzó frecuentemente y gesticuló con vigor con los brazos en alto para hacer hincapié en sus afirmaciones" (Clarín, 31/03/1964, p. 2).

O tom da notícia sobre a ameaça de greve por parte da CGT, em caso de golpe, pode ser percebido pelo modo como se redigiu a introdução, em destaque do texto: "la poderosa Confederación General de Trabajadores, dominada por comunistas, amenazó hoy decretar una huelga general 'si se diera o se intentara un golpe de estado contra el presidente João Goulart"” (Clarín, 31/03/1964, p. 3).

É significativo notar que o Clarín, assim como vários outros órgãos da grande imprensa no Brasil e na Argentina, emprestou visibilidade, nesse dia ou nos dias que seguem, a matérias produzidas pela AP, ANSA e outras agências, que dão conta da posição da diplomacia e de parte da grande imprensa dos Estados Unidos a respeito da crise brasileira. Quanto ao setor diplomático, noticia-se que "el Departamento de Estado norte-americano dijo que el presidente João Goulart no solo há tolerado el crecimiento del comunismo en Brasil sino que su gobierno se há 'negado a cooperar con eficacia' en medidas contra la dictadura comunista de Fidel Castro en Cuba" (Clarín, 31/03/1964, p. 2). E segue: "la influencia de comunistas y extremistas de izquierda en grupos laborales, campesinos y estudantiles, así como 'en las fuerzas armadas y otros sectores' es 'tolerada por el presidente Goulart', indicó el Departamento en su estudio de asuntos de la guerra fria desde 1960".

Colado no texto, a reprodução, recorrente na grande imprensa, de editorial célebre do vespertino norte-americano Washington Star, transcrito uma vez mais na representação generalizada de uma "posição da imprensa":

[...] el señor Goulart no impresiona favorablemente en este momento. Há estado en muy buenos términos con los comunistas, de una forma que sugiere que podría estar dispuesto a abrazarlos. Es esta una situación en la que un buen golpe efectivo [...] por parte de los líderes militares conservadores podría servir bien a los mejores intereses de toda América. De otra forma el régimen de Goulart podría llevar a los brasileños cuesta abajo, por la senda florida que lleva a un dominio comunista (Clarín, 31/03/1964, p. 2).

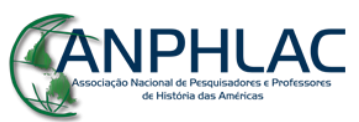

Revista Eletrônica da ANPHLAC, ISSN 1679-1061, №. 18, p. 189-222, jan./jul. 2015. http://revista.anphlac.org.br/ 
A crise brasileira noticiada aos argentinos pelo Clarín constituiu assim uma cadeia de acontecimentos construídos a partir do pano de fundo de uma ideologia da solução golpista autoritária, fundada essencialmente no anticomunismo e suas derivações contextuais. O golpe de Estado propriamente surgirá como uma culminância dessa narrativa.

$\mathrm{Na}$ edição de $1^{\mathrm{o}}$ de abril, as notícias da crise política brasileira seguem ocupando a primeira página do Clarín. Sob uma grande chamada, "Brasil en Armas", põe-se em destaque central uma radiofoto da AP, exclusiva para o periódico argentino, que foca um militar do IV Exército brasileiro, sediado no epicentro golpista em Minas Gerais, aparentemente armando uma metralhadora de solo, em uniforme de combate, segundo informa a legenda. Ao longo de seis páginas da edição, o diário equilibra matérias da AP, da AFP e da ANSA, em que se dá voz aos líderes golpistas, com destaque para Magalhães Pinto, Olimpio Mourão Filho e Adhemar de Barros, bem como aos pronunciamentos do governo, sobretudo do próprio Goulart.

$\mathrm{O}$ discurso dos amotinados reafirma os pontos essenciais da justificativa para a ruptura institucional, sempre fundados na "comunização" iminente do país, ora liderada, ora permitida pelo presidente da república, o que coloca o golpe como ação preventiva, em nome de princípios - mais que políticos - nacionais, e mesmo civilizatórios. Os manifestos presidenciais reproduzidos mostram, por outro lado, um Goulart energicamente disposto a defender seu governo e a ordem constitucional, se necessário no plano militar, a partir do I Exército, cujo comando ordenara ações de invasão e censura a órgãos da mídia oposicionista. A CGT aparece com grande destaque, em manchetes desde a primeira página, declarando greve geral em apoio ao governo. As agências internacionais dão destaque, reproduzido timidamente no Clarín, à voz de um Juscelino Kubistchek conclamando à paz e à conciliação nacional, sem referir exatamente em que termos. Uma das principais manchetes da cobertura é retirada da manifestação do governador paulista Adhemar de Barros e parece informar a expectativa que se constrói: "La Lucha Puede Prologarse Varios Meses" (Clarín, 01/04/1964, p. 5).

\section{CANPHLAC}

Revista Eletrônica da ANPHLAC, ISSN 1679-1061, №. 18, p. 189-222, jan./jul. 2015.

http://revista.anphlac.org.br/ 
Juntamente com este material das agências, o Clarín publica na mesma edição o primeiro texto do enviado especial ao Brasil que, como tal, representa, segundo os fundamentos estruturais e ideológicos do campo jornalístico, uma voz "propriamente argentina", ligada institucionalmente ao periódico e à construção da notíciaacontecimento que, por variados meios, ali se opera. $\mathrm{O}$ texto recebe o significativo título-manchete "Cuando Pelean los de Arriba” (Clarín, 01/04/1964, p. 4).

O autor relembra inicialmente a seu leitor argentino a renúncia de Jânio Quadros, em 1961, como origem mais próxima do que cita como o presente "redemoinho" no mar da política do país vizinho. Logo a seguir trata de construir a narrativa recorrente, como se viu, da apatia popular diante da extrema gravidade dos "acontecimentos" de arriba:

A primera vista, para un marciano que caiga en la Avenida Rio Branco, por ejemplo, aqui no pasa nada. Al hombre común parece importarle poco el momento dramático por que atraviesa Brasil, y en que posiblemente se este jugando el destino de la democracia y de las instituciones en ese país. Parece importarle poco, pero no es así: lo que pasa es que se siente impotente.

Como testemunho dessa apatia impotente, dá-se voz a um taxista carioca com quem supostamente falara o autor-jornalista, enquanto o dito personagem "se empeñaba en violar sistemáticamente, una a una, todas las normas de tránsito”, em imagem de um assim reputado espírito popular brasileiro, construída no colorido estilo new journalism:

Qué quiere que le diga...Esto seguramente va a terminar como todas las peleas que hubo siempre entre 'los de arriba': uno gana, el otro pierde, y nosotros seguimos como antes. Además, yo no puedo hacer nada; bastante trabajo tengo con ganar una feijoada para mi mujer y mis cuatro hijos... Y no se olvide - nos dice al final - que en Brasil las cosas se arreglan siempre solas.

Além de construir o título, como se viu, a partir dessa fala do homem comum, ficcional ou não, o autor constrói uma racionalização inicial sobre a crise brasileira em torno desta suposta característica da vida nacional, segundo a qual as coisas "se ajeitariam por si mesmas", sem grandes atos de vontade coletiva, a qual se

\section{GANPHLAC}

Revista Eletrônica da ANPHLAC, ISSN 1679-1061, №. 18, p. 189-222, jan./jul. 2015. http://revista.anphlac.org.br/ 
incorpora ao discurso jornalístico na qualidade do que seria "mais um mistério" do Brasil. Todavia, indaga retoricamente o autor, referindo-se ao momento presente: "Y el dia en que no se arreglen?" A resposta é significativa para uma interpretação de fundo dos acontecimentos vertidos como notícia e certamente expressiva para o leitor argentino: "Ese día temblaremos todos, porque los que temen que Brasil pueda llegar a ser otra Cuba, se quedan muy cortos: si Brasil se da vuelta, no va a ser otra Cuba; será otra Rusia, lo que es muy distinto".

É com base nessa possibilidade catastrófica para o olhar anticomunista latino-americano que o jornalista argentino trata de preservar sua posição objetiva frente à indefinição de rumos na política brasileira, afirmando que "resulta harto difícil decir quién va a salir vencedor en esta 'cinchada' política" e que "todos tienen un poco de razón y un poco de culpa". Após distribuir razões e culpas entre o governo e os golpistas, o enviado especial não deixa de ser fiel ao espírito legalista do periódico que o emprega sustentando que "pregonar abiertamente la subversión del orden institucional, eso no tiene justificación alguna".

A edição de 2 de abril ainda apresenta a crise brasileira dominando a primeira e mais seis outras páginas do Clarín. Na grande chamada em manchete que encabeça inteiramente a primeira página lê-se: "Goulart: dispuesto a resistir la Rebelión". Abaixo, ocupando mais da metade direita da página, radiofotos da AP de Olimpio Mourão Filho, chamado na legenda de "líder rebelde" e do presidente da Câmara de Deputados Ranieri Mazzili, cuja legenda vem com a indagação "otra vez presidente?" Entre ambos, uma formação de tanques em frente ao Ministério da Guerra, no Rio de Janeiro. Igualmente em grandes manchetes o leitor argentino, em um passar de olhos pela vertical direita, fica informado de que Carlos Lacerda anunciara a renúncia de Goulart, de que oito estados haviam se sublevado, de que houve confrontos militares no Rio, de que Goulart instalara sede de governo em Porto Alegre.

Nas páginas interiores as notícias são detalhadas, sempre com base em material das agências AP, AFP e ANSA, cuja seleção pela redação do Clarín parece obedecer a um equilíbrio quantitativo razoável, no jogo de informações e contrainformações entre aquelas favoráveis ao governo e as a favor dos "rebeldes", dentro dos padrões ideológicos da objetividade jornalística. Todavia, por coincidência ou não, a

\section{GANPHLAC}

Revista Eletrônica da ANPHLAC, ISSN 1679-1061, №. 18, p. 189-222, jan./jul. 2015. http://revista.anphlac.org.br/ 
primeira dessas páginas interiores, de número 2, é inteiramente dominada por notícias que tendiam a indicar a vitória golpista. A grande manchete que encabeça a página é: “Anunciaron los Rebeldes que Dimitió el Presidente y que Había Asumido Mazzili”.

O texto explicativo inicial em destaque compõe breve narrativa, cujo teor, de fundo informativo, parece colocar o golpe em posição francamente favorável ao olhar anticomunista: "El Ministerio de Guerra anunció esta noche que el presidente Goulart renunció a consecuencia de la poderosa rebelión político-militar contra su régimen izquierdista". As construções "poderosa rebelião político-militar" e "regime esquerdista" dispensam comentários nesse sentido. Importa destacar, de fato, o potencial ideológico de uma notícia assim construída.

Ao longo dos parágrafos de detalhamento das informações, na mesma página, com material das mesmas agências, veem-se operações análogas. Dá-se ali voz unicamente a Carlos Lacerda - que surge na cena dos acontecimentos atacado pela infantaria da marinha no palácio da Guanabara, prometendo lutar "até a morte" em nome da democracia e, em seguida, na televisão, anunciando a vitória próxima e a vacância da presidência da República em virtude do "desaparecimento" de Goulart - e a Adhemar de Barros, que aparece advertindo que "la mala hierba de la infiltración comunista continúa siendo amenazadora”. No plano militar, noticia-se a adesão à rebelião do II Exército, com base em São Paulo, e uma divisão de forças no I Exército.

Com destaque, no canto superior direito da mesma página, cercado por demarcação, coloca-se texto, com base em material da AP, sob a chamada "Festejaron en Copacabana el Anuncio de la Renuncia”. Se Copacabana simboliza, para um olhar estrangeiro ou mesmo nacional, certo espírito do Brasil, é extraordinariamente significativa, como potencial ideologia de respaldo ao golpe em processo, a notícia assim constituída no centro dos acontecimentos:

La noticia del derrocamento del régimen del presidente João Goulart creó esta noche ambiente de carnaval en el distrito de Copacabana. Desde las ventanas de los altos edifícios la gente agitaba sábanas, toallas blancas y pañuelos. 'Ahora nos toca a nosotros', gritava la gente en las calles. 'Viva Lacerda'. En la Avenida Atlántica de la playa y en la Avenida de Copacabana, la principal calle comercial del distrito, se reunieron centenares de automovillistas que tocaban las bocinas de sus vehículos. Otros millares de ciudadanos paseaban por la calle agitando

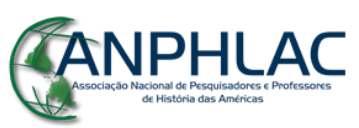

Revista Eletrônica da ANPHLAC, ISSN 1679-1061, №. 18, p. 189-222, jan./jul. 2015. http://revista.anphlac.org.br/ 
banderas y emitiendo gritos de alegria. Desde lo alto de los edifícios, los vecinos lanzaban nubes de papel picado de múltiples colores.

A página 3 seguinte é composta por material das agências com teor supostamente favorável ao governo em resistência, compondo o equilíbrio informativo antes mencionado, o qual, ao sublinhar a objetividade do discurso jornalístico, mais reforça o potencial ideológico das notícias, na direção em que vimos aqui discutindo. A página é encabeçada pela manchete "Goulart Resistirá en Porto Alegre", sob a qual põese o texto introdutório em destaque: "el presidente y su familia salieron esta noche en avión desde el aeropuerto militar de Brasilia con destino a Porto Alegre, donde su cuñado Brizzola tiene bajo su control al Tercer Ejercito". E segue: “Al tomar el avión, Goulart prometió que 'luchará hasta la muerte para defender su mandato como presidente". Seria esta a última vez que a imagem de um Goulart enérgico e decidido na defesa de seu governo apareceria nas páginas do Clarín. E de todos os jornais do mundo que optaram pela utilização do material da AP assim composto.

Favorecendo ainda a Goulart, o Clarín destaca no canto superior direito, encerrada em marcação pontilhada, a mensagem presidencial em material da ANSA na qual o primeiro mandatário brasileiro reafirma sua intenção de opor resistência ao golpe, bem como sublinha os projetos de reforma de seu governo e sua filiação democrática e cristã.

Abaixo, em destaque, as ações de Brizola, anunciando em cadeia de rádio a fuga do governador Ildo Meneghetti da capital; o controle legalista do III exército, a mais poderosa divisão do país; e realizando comício, no qual solicitava voluntários para a defesa armada do governo e instava os sargentos a deter os oficiais em todas as guarnições do país, a exemplo da quinta divisão de cavalaria de Bagé [RS]. Considerando-se a imagem já amplamente consolidada na grande imprensa de um Brizola "comunista" e "agitador", a matéria, que destaca o deputado pela Guanabara no comando prático da resistência, certamente pode ter tido um efeito dramaticamente contrário à continuidade da ordem constitucional no Brasil, ao menos para certo público leitor argentino.

Em meio a tais notícias compostas e distribuídas com base em material das agências, o Clarín posiciona em grande destaque o texto de seu enviado especial Luis

\section{GANPHLAC}

Revista Eletrônica da ANPHLAC, ISSN 1679-1061, №. 18, p. 189-222, jan./jul. 2015. http://revista.anphlac.org.br/ 
Sciutto, com título que encabeça totalmente a página: "Rio: una Ciudad en Confusión" (p.4). Situando pessoalmente a análise a partir de impressões sombrias de uma chuvosa Rio de Janeiro, cuja população seria "la parte viva, tangible, de esta tragedia", o autor trata de definir para seu público leitor argentino o que seriam os dois "bandos" em confronto na crise brasileira: por um lado, los que exigen imperiosamente la destitucón de Goulart bajo la doble acusación de violar la Constitución y actuar bajo la influencia comunista; por el otro, los que se apoyan - o los que dicen apoyarse - en las legiones populares a las que el ascetismo, el desalliento y, por qué no decirlo, la desesperación, colocaron en evidente posición hacia la izquierda".

O aparente caráter descritivo dos termos sumários da pugna assim posta não esconde, antes revela sem afirmar - o que potencializa sua provável atuação ideológica - que um dos lados tem acusações diretas a apresentar; o outro constitui-se a partir de um apoio que, de resto, pode ser somente retórico, em massas populares difusas e “desesperadas", jogadas irracionalmente, em virtude deste desespero, para certa posição política, a qual, exatamente, compõe a acusação dos primeiros... Os termos recorrentes do discurso anticomunista latino-americano aí estão, sem evidenciar-se na análise imparcial do autor, cujo texto sempre busca a condenação, tão somente, da situação conflitiva como um todo.

Essa direção sutil de uma provável leitura do texto é reforçada quando o autor relata a seu público o que chama de guerra radiofônica. Como só lhe fora possível ouvir a governista Rádio Nacional, Sciutto afirma que, até a metade do dia anterior, a vitória de Goulart parecia certa pelos informes e manifestações que ali se ouviam. À medida, porém, que o presidente se vira forçado a deixar a antiga capital federal, "poco menos que en plán de fuga", seus apoiadores teriam se tornado progressivamente violentos nas manifestações radiofônicas:

Las emissiones radiales transmitidas desde el palacio de Jango Goulart perdieron censura y se manifestaron rápidamente furibundas. Como elementos sitiados en una fortaleza y convencidos de que la resistencia es imposible los informes de Radio Nacional fueron aumentando la violencia de sus ataques. A las 14:30 se escucharon cosas como éstas: 'Es esta una lucha de las izquierdas contra las derechas, una lucha de liberación nacional sin conciliación posible, porque en ella se enfrentan

\section{GANPHLAC}

Revista Eletrônica da ANPHLAC, ISSN 1679-1061, №. 18, p. 189-222, jan./jul. 2015. http://revista.anphlac.org.br/ 
los que quieren la justicia social contra los que quieren mantener sus privilegios'.

O texto diz, sem absolutamente dizer, que, à medida que o conflito se agudizava e Goulart perdia o controle direto sobre suas forças de apoio, o caráter comunista - ou populista ou anticonstitucional de alguma forma, ao gosto potencial de uma certa comunidade de leitores - destas forças se revelava por inteiro em sua violência política, excludente de qualquer conciliação. E, em tom levemente irônico e sempre sem julgamento explícito de méritos ou conteúdos políticos das forças em contenda, o autor trataria de lembrar a seu público a similitude das conjunturas brasileira e argentina:

Para quien llega de Buenos Aires, no puede sorprenderle ni la guerra radiofônica, ni el despliegue de carros de guerra por calles y avenidas. Estábamos tan familiarizados con este tipo de entretenimiento que periódicamente se ofrecia a nuestros conciudadanos, que [...] hallamos una gran similitud fraterna entre aquellos denominados planteos y este grave trance.

A aparente leveza formal e o tom irônico do texto reforçam notavelmente a possível atuação ideológica do discurso jornalístico opinativo, no sentido de colocar a situação crítica no país vizinho como espelho para a "democracia tutelada" argentina, na qual o peronismo em suas faces partidária e sindical seguia em atuação, não obstante a proscrição legal e o exílio do líder maior, ou mesmo como uma naturalização dos golpes de Estado, em certa imagem da América Latina como um todo.

Na edição de 3 de abril, o Clarín noticiava ao público argentino o desenlace inicial da crise no país vizinho. A primeira página era totalmente encabeçada pela manchete "Fue Deposto Goulart", vindo abaixo, juntamente com radiofoto da AP na qual Mazzili recebe cumprimentos pela posse no Congresso, os textos introdutórios das matérias, que estariam redigidas em seis páginas internas. Neles informa-se que Goulart estaria em paradeiro desconhecido no estrangeiro e que fora decisiva a adesão do III Exército à "revolução", termo que aparece pela primeira vez, ao menos nas edições aqui examinadas.

\section{CANPHLAC}

Revista Eletrônica da ANPHLAC, ISSN 1679-1061, №. 18, p. 189-222, jan./jul. 2015. http://revista.anphlac.org.br/ 
A página seguinte, que abre a série de matérias sobre a queda do presidente brasileiro, novamente, por coincidência ou não, confere destaque de chamada para uma grande comemoração carioca (brasileira?) em torno do desenlace da crise. A manchete que encabeça a página diz: "Brasil: Al Triunfar la Rebelión Joao Goulart Dejó Porto Alegre”. E logo: “En Río, un millón de Personas Aclamó su Caída”. O texto, com base em material da AP, repete a descrição de um grande júbilo popular:

Más de un millón de alborozados brasileños recorrió hoy las calles principales de Rio de Janeiro, en tumultuosa celebración por la caída de Goulart, y de la vitoria de los dirigentes políticos y militares que actuaron para impedir lo que calificaron como una ocupación estilo Cuba. La multitud fue la mayor que se ha visto en Rio de Janeiro en qualquier acto político, y colmaba diez quadras de la Avenida Rio Branco. [...] Lo más impresionante era el enorme número de banderas brasileñas. Uno de los grupos de manifestantes llevaba un retrato del presidente Kennedy y un emblema de la cooperación brasileña-norteamericana en la Alianza para el Progreso. [...] En un punto de la demostración cerca de veinte cuadras estaban completamente ocupadas por la gente. Algunos cálculos hicieron ascender el número de la multitud a dos millones de personas.

A construção objetiva dos acontecimentos assim posta parece emoldurar o desfecho do golpe no Brasil com um respaldo popular - a ser avaliado, ou não, pelos leitores argentinos - e dos demais jornais do mundo que recepcionaram o material da AP, frise-se novamente.

A cobertura da mesma edição confere destaque, sempre alicerçada em material das agências, ao respaldo do governo e da grande imprensa, sempre à base de uma mitológica Opinião Pública dos Estados Unidos à deposição do presidente constitucional brasileiro. O conjunto do material informativo a respeito é encimado pela manchete: "EE. UU. Robustecerá sus Relaciones con Brasil" (p. 4).

A seguir, reproduz-se parte da mensagem do presidente Johnson, que cumprimenta Ranieri Mazzilli e aponta para um rápido estreitamento das relações de amizade e cooperação bilaterais. As opiniões dos principais jornais estadunidenses são igualmente reproduzidas, dentre elas parece emblemática em muitos sentidos a do New York Times:

\section{GANPHLAC}

Revista Eletrônica da ANPHLAC, ISSN 1679-1061, №. 18, p. 189-222, jan./jul. 2015. http://revista.anphlac.org.br/ 
Una vez más el Ejército está demostrando que es el árbitro de la situación política brasileña. João Goulart es y fue siempre hombre de izquierda. Se le podia calificar de socialista de salón. Su más grande desventaja es la ineficacia sin remedio que há demostrado. Sus enemigos no pueden probar que quiso hacer pasar a Brasil al campo comunista, pero sí que llevó el país al caos.

Nota-se, pois, que as matérias informativas que constroem o desfecho da crise brasileira como acontecimento no Clarín - e, de resto, em inúmeros outros órgãos da imprensa empresarial latino-americana, inserida, como tal, no fluxo internacional de informações via agências - constituem potencialmente variados sentidos para o golpe de Estado: como fato respaldado por boa parte da população e, no jogo internacional da Guerra Fria, conduzindo o país a relações privilegiadas com Washington, para além do afastamento já longamente requerido de um presidente inapto e sujeito ao controle de forças políticas que pensava controlar. Uma verdade objetiva de tais fatos, consubstanciada pelo discurso jornalístico moderno, é, como aqui se discute, precisamente o fundamento maior de uma ideologia da solução autoritária, ao menos para certa parcela do público habilitada a uma leitura com base nos princípios mais ou menos explícitos do conservadorismo anticomunista de variados matizes.

Todavia, se o discurso jornalístico assim colocado pode ser uma instância poderosa de construção e difusão de sentidos para a solução autoritária da crise brasileira como um momento político supostamente de transição ou mesmo depuração anticomunista - talvez como paradigma para crises análogas no cenário sul-americano, particularmente argentino -, este mesmo discurso é, pela natureza institucional da instância que o produz e veicula, absolutamente inconciliável com o estabelecimento de uma nova ordem, de caráter ditatorial, que tenda a violar, pela censura e repressão extra legal sistemáticas, em longo prazo, o ordenamento básico do Estado de Direito, essencial para a própria existência institucional da grande imprensa moderna, em seu liberalismo de profissão como fundamento discursivo básico. Não é de estranhar, pois, que boa parte da grande imprensa no Brasil e na Argentina - a qual, direta ou indiretamente, constituiu sentidos explicativos e legitimadores para as rupturas institucionais nela exibidas como transitórias e depuradoras, em 1955, 1964, 1966, para exemplificar, diante da conformação de regimes autoritários de longo prazo - passou a ostentar, mais ou menos rapidamente, posição francamente opositora a estes, sofrendo

\section{GANPHLAC}

Revista Eletrônica da ANPHLAC, ISSN 1679-1061, №. 18, p. 189-222, jan./jul. 2015. http://revista.anphlac.org.br/ 
os efeitos em larga escala dos sistemas de censura e repressão, como largamente sabido, e se consumando posteriormente como ator fundamental nas chamadas redemocratizações.

Nessa direção, é emblemático o posicionamento do enviado especial do Clarín ao Brasil. Em seu primeiro texto diante do desfecho da crise que viera cobrir, na edição de 3 de abril Luis Sciutto reafirma os termos fundamentais da construção de sentido para o golpe. Novamente culpa fundamentalmente Goulart, conferindo-lhe inaptidão, descontrole de suas bases de apoio excessivamente à esquerda e possível iniciativa golpista em seus derradeiros momentos na presidência, sem deixar de sugerir analogia com a situação argentina:

\begin{abstract}
Enfrentando a Carlos Lacerda, el hombre de derecha, y apoyado por Leonel Brizzola, exaltado izquierdista teórico y además su cuñado, Jango se refugió en Porto Alegre. Se montó paralelamente una ficción de CGT, con su secretariado de profesionales que alardeaban de tener el movimiento obrero en sus manos (los argentinos conocieron este juego). Algún inspirado consejero ideó la locura de los marineros y de los sargentos. Trabajando con elementos tan endebles, Jango jugó y perdió. [...]. A esta hora [...] ya habrá atravesado la frontera. Brasil con su nuevo presidente declara su libertad recuperada y su democracia restablecida. La Libertad y la Democracia: siguen siendo bellas palavras (p. 23).
\end{abstract}

A frase final indicava as apreensões do autor-jornalista com os primeiros sinais de uma ordem que parecia surgir da tão bem justificada ruptura: o controle militar do Executivo e a ditadura. Na edição do dia seguinte, Clarín apresentava matéria com texto de seu enviado especial, a qual informava, em manchete, que "Oficiales de las Tres Fuerzas Exigen que se Nombre a un Presidente Militar" (p. 3). Em seu texto de análise da mesma edição, Sciutto, diante dos primeiros sinais da ditadura, apela para um nome que lhe parece essencial para conferir uma boa direção à ruptura institucional pela qual culpara, como praticamente toda a imprensa empresarial na Argentina e no Brasil, a Goulart, "más un soñador que un governante" (p. 4). O nome salvador vinha na chamada da matéria: "En la Hora de Kubitschek". Apesar dos maus sinais, o autor ainda mostrava confiança em lideranças, que reputava democráticas, simbolizadas pelo ex-

\title{
GANPHLAC
}

Revista Eletrônica da ANPHLAC, ISSN 1679-1061, №. 18, p. 189-222, jan./jul. 2015. http://revista.anphlac.org.br/ 
presidente, para efetivar o caráter transitório da ruptura, o que não deixa de dar certa continuidade à construção de sentidos para o golpe.

Todavia, na edição de 5 de abril, em seu penúltimo texto no Rio de Janeiro (o último seria uma extensa entrevista exclusiva com Juscelino Kubitschek, publicada na edição seguinte), o enviado do Clarín parece perder esperanças com o rumo da situação brasileira; antecipa notavelmente um tipo de racionalização que tardaria ainda meses, ou anos, para aparecer de forma hegemônica na grande imprensa, no Brasil e na Argentina:

Pero apenas se disiparon las nieblas de la confusión de tras de cuyos celajes cada actor emboscó sus intenciones, queda claro que Brasil, con el pretexto de la amenaza comunista, va camino de organizar un gobierno fuerte ejercido por militares, disfrazado de constitucionalidad y de duración sin término de tiempo. Políticos, intelectuales de las camadas arcaicas y periodistas de la máxima influencia en el sector de la victoria democrática que celebra Brasil, piden hoy la dictadura. Lo piden en otros términos: 'todo el poder al ejército', para que el gobierno que suceda al de Goulart esté libre de influencias políticas. Y la democracia, en cuyo santo nombre se hizo la revolución? (p. 4).

A manifestação do enviado especial assim fixada no Clarín explicita o liberalismo profissional do campo e não deixa de representar as formas complexas e contraditórias das muitas formas de atuação da grande imprensa no espaço público contemporâneo da América Latina.

\section{GANPHLAC}

Revista Eletrônica da ANPHLAC, ISSN 1679-1061, №. 18, p. 189-222, jan./jul. 2015. http://revista.anphlac.org.br/ 


\section{Referências Bibliográficas}

ALLEYNE, Mark D. International power and international comunication. London: Macmillan Press, 1995.

ALSINA, Miquel R. La construcción de la noticia. Barcelona, Buenos Aires: Paidós, 1996.

CAVLAK, Iuri. As relações entre Brasil e Argentina no início da Guerra Fria. História Debates e Tendências. Passo Fundo, V 6, n 2, 2007.

DA ORDEN, M. Liliana e PIRRO, Julio César M (comp.). Prensa y peronismo. Discursos, prácticas, empresas. Rosario: Prohistoria Ediciones, 2007.

DE RIZ, Liliana. La política en suspenso 1966/1976. Buenos Aires: Paidós, 2000.

DÍAZ, Marcela. Industrias culturales y formas de identificación política. Primera Plana y su rol en la caída de Illia In: LLAIRÓ, Maria de Monserrat (comp.). El gobierno de Arturo Illia y la restauración institucional. Las relaciones económicas internacionales y la crisis de gobernabilidad (1963-1966). Buenos Aires: Ediciones Cooperativas, 2007.

DONGHI, Tulio H. La democracia de massas, Buenos Aires: Paidós, 2000.

FREDERICK, Howard H. Global communication and international relations. California: Wadsworth Publishing Company, 1993.

GOLDWERT, Marvin. Democracy, militarism and nationalism in Argentina, 19301966. Austin e Londres: University of Texas Press, 1972.

LLAIRÓ, Maria de M. e SIEPE, Raimundo. Frondizi un nuevo modelo de inserción internacional. Buenos Aires: EUDEBA, 2003.

LONGHI, Raquel R. e SILVEIRA, Mauro C. A convergência de linguagem nos especiais do Clarín.com. Ver. Estud. Comum. Curitiba, v. 11, n.25, p. 157-166, maio/ago. 2010.

NORA, Pierre. O retorno do fato. In: LE GOFF, J. e NORA, P. História: Novos Problemas. Rio de Janeiro: F. Alves, $2^{\mathrm{a}}$ ed., 1979.

PANDOLFI, Rodolfo e GIBAJA, Emilio. La democracia derrotada. Arturo Illia y su Época. Buenos Aires: Lumiere, 2008.

\section{CANPHLAC}

Revista Eletrônica da ANPHLAC, ISSN 1679-1061, №. 18, p. 189-222, jan./jul. 2015.

http://revista.anphlac.org.br/ 
PIZARRO, A. Marcela. El "mundo" de la prensa argentina. Que es noticia internacional para La Nación y Clarín. Buenos Aires: Universidad Austral, 2008.

POTASH, Robert. El Ejercito y la política en la Argentina 1962-1973, 2 vol. Buenos Aires: Ed. Sudamericana, 1994

RAPOPORT, Mario e LAUFER, Rubén. Os Estados Unidos diante do Brasil e da Argentina: os golpes militares da década de 1960. Revista Brasileira de Política Internacional, n. 43, 2000.

ROMERO, Luis A. Breve Historia Contemporánea de la Argentina. Buenos Aires: Fondo de Cultura Económica, 2004.

SÁNCHEZ, Pedro. La presidencia de Illia. Buenos Aires: Centro Editor de América Latina, 1983.

SIRVÉN, Pablo. Perón y los medios de comunicación. La conflictiva relación de los gobiernos justicialistas con la prensa (1943-2011). Buenos Aires: Sudamericana, 2011.

SODRÉ, Muniz. A narração do fato. Notas para uma teoria do acontecimento. Petrópolis: Vozes, 2009.

TARONCHER, Miguel A. La caída de Illia. La trama oculta del poder mediático. Buenos Aires: Javier Vergara Ed, 2009.

THOMPSON, John B. Ideologia e cultura moderna. Teoria social crítica na Era dos Meios de Comunicação de Massa. Petrópolis: Vozes, 1995.

THUSSU, Daya K. International communication: continuity and change. London, New York: Oxford University Press, 2000.

ULANOVSKY, Carlos. Paren las rotativas. Diarios, revistas y periodistas (1920-1969). Buenos Aires: Emecé Editores, 2005.

\section{GANPHLAC}

Revista Eletrônica da ANPHLAC, ISSN 1679-1061, №. 18, p. 189-222, jan./jul. 2015. http://revista.anphlac.org.br/ 